\title{
PENDIDIKAN PEREMPUAN PERSPEKTIF QURAISH SHIHAB DALAM TAFSIR AL MISBAH
}

\author{
Oleh: \\ Dhomirotul Firdaus \\ Zaenal Arifin \\ fierda.zereya.fz@gmail.com,zae.may13@gmail.com \\ Institut Agama Islam Tribakti (IAIT) Kediri
}

\begin{abstract}
The focus of this article is to discuss how the conception of a woman's position according to M. Quraish Shihab in his book "Tafsir al Misbah". The writing of this article is motivated by the fact that society today still positions women in a marginal position, despite the fact that many Moslems thinkers argue that women have the same dignity as men. And even among certain (urban) communities, women have become drivers of social, economic and political change. But understanding the Indonesian people (especially rural) still positions women in marginal positions. This study generate several conclusions, first, that women's education must be emphasized more on the principle of sharing in improving quality rather than competence to win and lose, continuously empowering, strengthening with religious material, and starting early. Second, according to M. Quraish Shihab women's education is oriented towards material (physical) and immaterial (mind and soul). And third, the paradigm and thought map of M. Quraish Shihab is a critique of the conservative and liberal paradigms, where education should free women from subordination and marginalization due to the discriminative ideology adopted by the people today, as a reflection of religious interpretations of the community against religious teachings, impressive concern for the issue of social injustice, lawsuit for gender discrimination, and social issues.
\end{abstract}


Fokus pada artikel ini adalah membahas tentang bagaimana konsepsi kedudukan perempuan menurut $\mathrm{M}$. Quraish Shihab dalam bukunya "Tafsir al Misbah". Penulisan artikel ini dilatarbelakangi dengan fakta masyarakat saat ini yang masih memposisikan perempuan dalam posisi yang marginal, meskipun sebenarnya telah banyak pemikir muslim yang berpendapat bahwa perempuan memiliki martabat yang sama dengan kaum laki-laki. Dan bahkan di kalangan masyarakat tertentu (perkotaan), perempuan telah menjadi penggerak perubahan sosial, ekonomi dan politik. Namun mainstrem masyarakat Indonesia (khususnya pedesaan) masih memposisikan perempuan di posisi yang marginal. Studi ini menghasilkan beberapa kesimpulan, pertama, bahwa pendidikan perempuan harus lebih ditekankan pada prinsip saling berbagi dalam meningkatkan kualitas bukan kompetensi untuk menang dan kalah, kontinyu melakukan pemberdayaan, melakukan penguatan dengan materi agama, dan dimulai sejak dini. Kedua, menurut M. Quraish Shihab pendidikan perempuan diorientasi pada unsur material (jasmani) dan imaterial (akal dan jiwa). Dan Ketiga, peta paradigma dan pemikiran M. Quraish Shihab merupakan kritik terhadap paradigm konservatif dan liberal, di mana pendidikan seharusnya membebaskan kaum perempuan dari subordinasi dan marginalisasi akibat ideologi diskrimatif yang dianut masyarakat saat ini, sebagai cerminan dari tafsiran keagamaan masyarakat tehadap ajaran agama, mengesankan kepeduliannya terhadap persoalan ketidakadilan sosial, gugatan atas diskriminasi gender, dan persoalan sosial.

Kata Kunci: Pendidikan Perempuan, KH. M. Quraish Shihab, Tafsir al Misbah.

\section{Pendahuluan}

Melihat sejarah umat manusia, hampir di belahan bumi manapun menyatakan bahwa posisi perempuan dianggap sebagai makhluk kedua setelah kaum laki-laki. Sejarah Yunani 
Kuno misalnya, perempuan dianggap tidak lebih dari sekedar komoditi, di kalangan elit perempuan disekap di istana, dan di kalangan bawah perempuan menjadi komoditi yang dapat diperjual-belikan. ${ }^{1}$ Dalam peradaban Yunani Kuno perempuan dapat diklasifikasikan ke dalam 3 (tiga) macam, yaitu; pelacur, selir dan istri yang hanya bertugas merawat dan membesarkan anak. $^{2}$

Sementara kaum Yahudi menempatkan perempuan sebagai pelayan, bahkan seorang ayah berhak menjual anak perempuannya tanpa ada pilihan dari pihak anak perempuannya. ${ }^{3}$ Selain itu, bagi kaum Yahudi dan Nasrani, perempuan (Hawa) merupakan sumber kejahatan dan dosa, perempuan menjadi penyebab laknat abadi bagi Adam dan keturunannya, perempuan dihukum dengan pesakitan saat melahirkan, dan perempuan dianggap sebagai makhluk najis saat mengalami menstruasi. ${ }^{4}$

Demikian juga dalam masyarakat Islam, meskipun dalam al-Quran telah dijelaskan bahwa setiap manusia memiliki derajat yang sama, baik laki-laki maupun perempuan, yang membedakan hanyalah persoalan ketakwaan. Namun faktanya masyarakat Islam masih menganggap perempuan sebagai makhluk kedua setelah kaum laki-laki. Derajat perempuan masih berada di bawah derajat kaum laki-laki. Seperti hak waris, diharamkannya perempuan memasuki masjid ketika menstruasi, tidak diperbolehkan menjadi imam shalat bagi kaum laki-laki, tidak diwajibkan shalat Jumat, dan sebagainya. Perbedaan perlakuan tersebut, tidak lepas dari perbedaan kodrat laki-laki dan perempuan, jika perempuan mengalami masa menstruasi, melahirkan dan berfisik lemah, sementara laki-laki sebaliknya. Meskipun perlakuan tersebut didasarkan pada ayat-ayat al

${ }^{1}$ Sayid Muhammad Husain Fadhlullah, Dunia Wanita dalam Islam, (Lentera, Jakarta, $\mathrm{tt}$ ).

2 R Magdalena, "Kedudukan Perempuan Dalam Perjalanan Sejarah (Studi Tentang Kedudukan Perempuan dalam Masyarakat Islam)” 2 (2013): h. 6 .

3 Siti Muslikhati, Feminisme dan Pemberdayaan Perempuan dalam Timbangan Islam (Jakarta: Gema Insani, 2004). h. 24.

${ }^{4}$ Muslikhati. h. 24. 
Qur'an dan Hadits sebagai sumber utama ajaran Islam, namun jika dilihat dari ayat al-Quran yang menyatakan bahwa setiap manusia memiliki derajat yang sama, hanya tingkat ketakwaan yang membedakannya, maka menurut hemat penulis diperlukan penafsiran ulang atas ayat-ayat al-Qur'an dan Hadits yang cenderung mendeskriminasikan kaum perempuan.

Dalam bidang pendidikan, khususnya masyarakat Islam, baik di perkotaan maupun di pedesaan, masih ditemukan perlakuan diskriminatif terhadap pendidikan kaum perempuan. Mereka menganggap, perempuan tidak perlu sekolah terlalu tinggi, meski secara finansial sebenarnya mampu. "Untuk apa perempuan sekolah terlalu tinggi, toh larinya ke dapur juga," Begitulah kira-kira pandangan mereka.

Pendidikan sebagai proses pembentukan pribadi karena pendidikan berfungsi sebagai sesuatu kegiatan yang sistematis dan sistemik terarah kepada terbentuknya kepribadian peserta didik. Pendidikan dapat diartikan sebagai proses penyiapan warga negara melalui kegiatan yang terencana untuk membekali peserta didik agar menjadi warga negara yang baik sesuai dengan cita-cita negara. 5

Kaum perempuan tidak hanya mengelola benda-benda mati, tetapi juga benda hidup, yaitu anak-anak sebagai generasi penerus bangsa. Tentu saja sangat berbeda mengelola benda mati dengan anak-anak, karena anak-anak mempunyai perasaan, kemauan dan pikirannya sendiri. Sungguh mendidik anak-anak itu adalah pekerjaan yang tidaklah mudah, sebab memang menyangkut berbagai aspek, yaitu kejiwaan, fisik, sosial, budaya dan juga ekonomi. Di sinilah dibutuhkan pengetahuan yang cukup agar seorang ibu dapat menjalankan tugasnya dengan baik.

Untuk mendapatkan pengetahuan tersebut, yaitu di antaranya bisa melalui pendidikan formal maupun non formal. Meskipun diakui, lembaga pendidikan formal kadang belum sepenuhnya mampu mendidik anak menjadi seorang yang siap menjadi "orang". Namun setidaknya lembaga ini memberikan

5 Wasito, Pendidikan Multikultural TRIBAKTI Jurnal Kebudayaan dan Pemikiran Keislaman (Kediri: IAIT Kediri, 2010), h. 77. 
bekal dasar yang cukup berharga bagi perkembangan diri seseorang.

Munculnya diskriminatif terhadap pendidikan perempuan itu disebabkan antara lain oleh kekeliruan penafsiran terhadap al-Qur'an tentang perempuan yang dilakukan oleh orang-orang yang kurang bertanggung jawab (kaum patriarki) dan masyarakat awam mengamini tanpa ada koreksi terlebih dahulu, padahal al-Qur'an sangat menjunjung tinggi kedudukan, harkat dan martabat perempuan. Dan juga disebabkan oleh kehidupan masyarakat yang sudah patriarki dan materialistis. Kehidupan sekarang seakan semuanya berpusat pada materi, termasuk dalam hal pendidikan. Sebagian masyarakat ada yang menganggap, karena sekolah itu mengeluarkan uang, maka nantinya harus menghasilkan uang pula. Sekolah terlalu tinggi di anggap mubadzir bila tidak menghasilkan uang pada akhirnya. Lulus sekolah berarti harus bekerja. Bila perempuan sekolah terlalu tinggi dan akhirnya tidak bekerja, maka akan dinilai mubadzir.

Agama Islam, seperti dikatakan di atas, mengajarkan bahwa mencari ilmu itu wajib tanpa mengaitkan dengan pekerjaan. Perintah Islam itu berspektrum luas, dunia dan akhirat. Karena ilmu menurut pandangan Rasulullah adalah sebagai tiang dunia dan tiang agama sebagaimana sabdanya yang artinya :"Siapa yang menginginkan dunia maka hendaklah ia berilmu, dan siapa yang menginginkan akhirat maka hendaklah ia berilmu dan siapa yang menghendaki keduanya maka hendaklah ia juga berilmu". ${ }^{6}$

Sementara al-Qur'an sudah menjelaskan juga bahwa perempuan memiliki harkat dan martabat yang sama dengan laki-laki terutama dalam hal pendidikan. Sudah banyak ayatayat al-Qur'an yang telah menyuarakan tentang kedudukan perempuan dan tidak ada diskriminatif di dalamnya, hanya saja kadang orang yang menafsirilah yang perlu dipertanyakan, mereka sering salah tafsir sehingga membuat tafsiran al-Qur'an menjadi kurang sempurna.

${ }^{6}$ Djumransjah, Dimensi-dimensi Filsafat Pendidikan Islam (Malang: Kutub Minar, 2005), h.73. 
Peran perempuan dalam pendidikan anak sangatlah besar yang akan membawanya pada pertumbuhan dan perkembangan yang diridhai Allah SWT untuk menjadi manusia yang shalih, cerdas dan terampil. Seorang ibu merupakan tokoh sentral dalam pendidikan anak, ibu menjadi suri teladan bagi anak-anaknya, terutama dalam sosialisasi norma-norma sosial anak. ${ }^{7}$ Orang pun sering mengatakan bahwa jika kita durhaka kepada ibu, nanti akan masuk neraka. Hadits ini menunjukkan bahwa peran perempuan sebagai pendidik. Jika ibunya baik, shalihah, beriman, terampil dan mampu mendidik anaknya ke jalan yang benar, anaknya akan menjadi shalih juga, karena seorang ibu adalah madrasatul ula bagi anaknya. ${ }^{8}$ Pada dasarnya seorang ibu harus menjadi pendidik, ia harus mendidik anak-anaknya kelak, untuk itu dia harus mendidik dirinya dahulu supaya mampu melaksanakan tugasnya sebagai pendidik untuk anak-anaknya kelak. Islam diturunkan ke dunia ini sebagai rahmat ke seluruh alam, termasuk kepada perempuan. Nilai-nilai fundamental yang mendasari ajaran-ajaran Islam seperti perdamaian, pembebasan dan egalitarianism. ${ }^{9}$ Termasuk persamaan derajat antara lelaki dan perempuan yang banyak tercermin dalam ayat-ayat alQur'an.

Dalam memandang posisi perempuan pada masa praIslam, mayoritas intelektual dan sejarawan terutama dari kalangan Islam, melihat perempuan sebagai sebuah gambaran kehidupan yang sangat buram dan memprihatinkan. Perempuan dipandang sebagai makhluk yang tidak berharga, menjadi bagian dari laki-laki, keberadaannya sering menimbulkan masalah, tidak memiliki independensi diri, hak-haknya boleh ditindas dan dirampas, tubuhnya dapat diperjualbelikan atau dapat diwariskan atau dimarginalkan, serta pandanganpandangan lainnya yang menegasikan posisi perempuan sebagai kaum yang lemah.

7 Firthiani Gade, Ibu Sebagai Madrasah dalam Pendidikan Anak, Jurnal Ilmiah Didaktika, Vol. XIII, No. 1, Agustus 2012.

${ }^{8}$ Fithriani Gade, Ibu Sebagai Madrasah.

${ }^{9}$ Ajaran Bahwa Manusia Yang Sederajat Sama Memiliki Takdir Yang Sama Pula. Sebagaimana dikutip oleh M. Dahlan Al-Barry, Kamus Ilmiah Populer (Surabaya : Arkola, 1994), h. 129.

Volume 29 Nomor 2 Juli-Desember 2018 
Semenjak Islam datang dengan membawa pesan moral kemanusiaan yang tidak ada tandingannya dalam agama manapun, ia tidak hanya mengajak manusia untuk melepaskan diri dari belenggu tirani kemanusiaan, tetapi lebih jauh mengajak membebaskan diri dari belenggu ketuhanan yang politis menuju kepada kebebasan dengan satu Tuhan Yang Maha Esa. Hal ini eksplisit dalam kalimat syahadat, ketika seseorang memasuki agama Islam, "Aku bersaksi bahwa tiada Tuhan selain Allah dan Muhammad utusan Allah."

Misi tauhid inilah yang menyebabkan Islam sangat efektif untuk menjadi basis gerakan transformasi keagamaan. Apabila pada masa sebelum kedatangan Islam dunia sangat diwarnai oleh imperialisme dan kolonialisme antar sesama manusia maupun antar kelompok, suku dan bangsa. Dengan demikian, secara horizontal tidak ada kekuatan yang mampu menekankan kebebasan individu lain, apakah itu negara, pemilik modal atau kekuatan individu, semuanya memiliki nilai dan perlakuan yang sama di hadapan Allah SWT.

Jika melihat hasil penelitian terdahulu berkaitan dengan pemikiran Quraish Shihab tentang perempuan tidak bisa dilepaskan dari bukunya yang berjudul "Tafsif al Misbah". Seperti artikel yang ditulis oleh Naqiyah Mukhta dengan judul "M. Quraish Shihab Menggugat Bias Gender Para Ulama" yang berkesimpulan bahwa pemikiran M. Quraish Shihab dalam kitab Tafsir Al-Misbah merupakan kritik terhadap mufassir yang cenderung subjektifitas dalam menafsirkan teks agama tentang perempuan. ${ }^{10}$ Lain halnya dengan Atik Wartini yang menulis artikel dengan judul "Tafsir Feminis M. Quraish Shihab; Telaah Ayat-ayat Gender dalam Tafsir al Misbah" yang memberikan kesimpulan bahwa Quraish Shihab berusaha menekankan bahwa diturunkannya al-Quran adalah untuk mengikis segala perbedaan antara kaum laki-laki dan perempuan. Dalam tafsir al Misbah Quraish Shihab hendak menempatkan perempuan dalam bingkai yang sama dengan laki-laki. ${ }^{11}$ Penelitian ini

${ }^{10}$ Naqiyah Mukhtar, M. Quraish Shihab Menggugat Bias Gender Para Ulama, Journal of Qur'an and Hadith Studies, Vol. 2, No. 2 (2013): 189-208.

11 Atik Wartini,Tafsir Feminis M. Quraish Shihab; Telaah Ayat-ayat Gender dalam Tafsir al Misbah, Palastren, Vol. 6, No. 2, Desember 2013. 214

Volume 29 Nomor 2 Juli-Desember 2018 
Pendidikan Perempuan... Oleh: Dhomirotul F. Eं Zaenal Arifin

dimaksudkan untuk mengkaji dengan lebih dalam lagi tentang pendidikan perempuan menurut pandangan M. Quraish Shihab, sehingga nantinya akan ditemukan bagaimana sebenarnya pendidikan perempuan di Indonesia dan ditemukan pula bagaimana rumusan-rumusan pendidikan perempuan menurut M. Quraish Shihab.

\section{Pembahasan.}

Menurut M. Qurais Shihab perempuan juga mempunyai derajat sama dengan laki-laki dalam menuntut ilmu pengetahuan dan ini sudah dibuktikan dalm kitab suci al-Qur'an dan al-Hadits juga dalam sejarah Nabi Muhammad, di mana pada waktu itu perempuan banyak yang berilmu bahkan sebagai perawi hadits. Sejarah membuktikan bahwa banyak perempuan yang sangat menonjol pengetahuannya dalam berbagai bidang ilmu pengetahuan sehingga menjadi rujukan sekian banyak tokoh laki-laki. Maka dari itu, konsep pendidikan perempuan ke depan menurut M.Quraish Shihab dapat diuraikan sebagai berikut:

\section{Tujuan Pendidikan Perempuan}

Dengan merujuk kepada ayat 2 surat al-Jumu'ah yang artinya "Dialah yang mengutus kepada kaum yang yang buta huruf seorang Rasul di aintara mereka, yang membacakan ayatayat-Nya kepada mereka, mensucikan mereka dan mengajarkan kitab dan hikmah (al-Sunnah). Dan sesungguhnya mereka sebelumnya benar-benar dalam kesesatan yang nyata." $12 \mathrm{M}$. Quraish Shihab berpendapat bahwa Rasulullah SAW, yang dalam hal ini bertindak sebagi penerima al-Qur'an, bertugas untuk menyampaikan petunjuk-petunjuk kepada orang-orang yang bertakwa sebagaimana tersebut dalam surat al-Baqarah ayat 2, mensucikan dan mengajarkan manusia. Mensucikan dapat diidentikkan dengan mendidik, sedangkan mengajar tidak

${ }^{12}$ Al-Qur'an dan terjemahnya, QS. Al-Jumu'ah, 62:2 h. 932.

Volume 29 Nomor 2 Juli-Desember 2018 
lain kecuali mengisi benak anak didik dengan pengetahuan yang berkaita dengan alam metafisika serta fisika. ${ }^{13}$

Tujuan yang dicapai dengan pembacaan, pensucian dan pengajaran tersebut adalah pengabdian kepada Allah sejalan dengan tujuan penciptaan manusia yang ditegaskan dalam alQur'an dalam surat al-Dzariyat ayat 56 yang artinya "Aku tidak menciptakan manusia dan jin kecuali unyuk menjadikan tujuan akhir atau hasil segala aktifitasnya sebagai pengabdi kapadaku."14 Aktifitas yang dimaksud tersimpul dalam kandungan ayat 30 surat al-Baqarah yang artinya ":Sesungguhnya aku hendak menjadikan khalifah di muka bumi", dan surat Hud ayat 61 yang artinya "dan Dia yang menciptakan kamu dari bumi (tanah) dan menugaskan kamu untuk memakmurkan". Artinya, manusia yang dijadikan khalifah itu bertugas memakmurkan atau membangun bumi ini sesuai dengan konsep yang ditetapkan oleh yang menugaskan yaitu Allah. ${ }^{15}$ Selanjutnya penulis dapat simpulkan bahwa pendidikan al-Qur'an adalah membina manusia secara pribadi baik itu laki-laki atau perempuan dan kelompok sehingga mampu menjalankan fungsinya sebagai hamba Allah dan khalifah-Nya. Karena melalui pendidikan, al-Qur'an menginginkan terwujudnya manusia yang terbina seluruh potensi dirinya, fisik, jiwa, dan akalnya sehingga terbentuk manusia yang seutuhnya. Oleh karena itu, al-Qur'an tidak mendeskriminasikan laki -laki dan perempuan dalam bidang pendidikan.

\section{Metode Pendidikan Perempuan}

Dalam hal ini menurut M. Quraish Shihab, al-Qur'an memandang dalam mengarahkan pendidikannya kepada

${ }^{13}$ M. Quraish Shihab, Wawasan al-Qur'an, h. 172.

${ }^{14}$ Al-Qur'an dan terjemahnya, h . 862.

${ }^{15}$ Abuddin Nata,Tokoh-Tokoh Pembaharuan Islam, h. 367. 
manusia khususnya kapada perempuan sebagaimana di atas. Karena itu, materi-materi pendidikan perempuan hampir selalu mengarah kepada jiwa, akal, dan raga manusia. Menurutnya penyajian materi pendidikannya, al-Qur'an membuktikan kebenaran materi tersebut melalui pembuktian-pembuktian, baik dengan argumentasi-argumentasi yang dikemukakannya, maupun yang dapat dibuktikan sendiri oleh manusia (peserta didik) melalui panalaran akalnya. ${ }^{16}$ Menurut penulis, hal ini dianjurkan oleh al-Qur'an untuk dilakukan pada saat menemukan materi tersebut, agar akal manusia merasa bahwa ia berperan dalam menemukan hakikat materi yang disajikan itu sehingga merasa memiliki dan bertanggung jawab untuk membelanya. Salah satu metode yang digunakan al-Qur'an untuk mengarahkan manusia ke arah yang dikehendaki adalah dengan menggunakan "kisah". Materi yang disajikan dalam al Quran selalu ditunjang dengan kisah-kisah umat-umat terdahulu, baik kisah tersebut benar-benar terjadi maupun kisah simbolik. Seperti yang dicontohkan oleh penulis, misalnya dalam surat alQashash. Bahkan al-Qur'an menganggap bahwa perempuan adalah salah satu unsur terpenting dalam suatu "kisah". Misalnya dalam surat Yusuf ayat 22-23. Di mana, al-Qur'an juga menggunakan kalimat-kalimat yang dapat menyentuh hati agar mengarahkan manusia kepada ide dan gagasan yang dikehendaki. Di samping itu, al-Qur'an juga menggunakan metode pembiasaan dalam rangka memantapkan pelaksanaan materi-materi ajarannya sehingga akhirnya melahirkan kebiasaan. Selain itu, menurut penulis, dengan menggunakan metode-metode tersebut terlihat jelas, bahwa al-Qur'an menuntun peserta didiknya untuk menemukan kebenaran melalui usaha peserta didik sendiri, menuntut agar materi yang disajikan diyakini kebenarannya melalui argumentasiargumentasi logika, dan kisah-kisah yang dipaparkannya

\footnotetext{
${ }^{16}$ M. Quraish Shihab, Wawasan al-Qur'an, h. 175.
} 
mengantarkan peserta didik kepada tujuan pendidikan itu sendiri dalam berbagai aspek, dan nasehatnya ditunjang dengan panutan.

Bahwa sifat pendidikan perempuan menurut M Quraish Shihab harus bersifat rabbani ${ }^{17}$, ini berdasarkan ayat pertama dalam wahyu pertama yang berbunyi iqra' yang artinya bacalah. Menurut penulis, objek dari iqra' masih bersifat umum, maka objek kata tersebut mencakup segala yang dapat terjangkau, baik ia merupakan bacaan suci yang bersumber dari tuhan maupun bukan, baik menyangkut ayat-ayat yang tertulis maupun yang tidak tertulis. Karena itu menurut penulis, perintah iqra' mencakup telaah terhadap alam raya, masyarakat, dan diri sendiri, serta bacaan tertulis, baik suci ataupun tidak, serta mempelajarinya secara terus-menerus. Melihat jangkauan yang harus dipelajari begitu luas, seseorang dalam hal ini peserta didik tidak dapat meraihnya dengan sempurna. Karenanya, ia dituntut untuk terus menerus belajar. Atas dasar inilah, Nabi pernah berkata "Tuntutlah ilmu dari buaian hingga ke liang lahat." 18

Menurut penulis, pendidikan seumur hidup ini tentunya tidak terlaksana melalui jalur formal saja, akan tetapi juga melalui jalur informal dan nonformal, atau dengan kata lain pendidikan seumur hidup menjadi tanggung jawab bersama keluarga, masyarakat, dan pemerintah. Bahkan lebih jauh dapat dikatakan bahwa al-Qur'an tidak hanya menekankan pentingnya belajar, akan tetapi juga pentingnya mengajar.

Dari hasil analisis tentang pendidikan perempuan menurut M. Quraish Shihab dapat diketahui, pertama, bahwa pendidikan perempuan harus lebih ditekankan pada prinsip saling berbagi dalam meningkatkan kualitas bukan kompetensi untuk menang dan kalah, sehingga perempuan tidak lagi terjerumus pada adu

\footnotetext{
${ }^{17}$ Abuddin Nata, Tokoh-tokoh Pembaharuan, h. 372.

${ }^{18}$ M. Quraish Shihab, Wawasan al-Qur'an, h. 178.
} 
domba kaum patriarki dan perempuan akan lebih melihat lakilaki sebagai partner untuk berkarya. Kedua, kontinu melakukan pemberdayaan, baik dilakukan secara formal maupun non formal, seperti melakukan pengajian rutin, membuka kursus keterampilan, dan lain-lain.

Ketiga, melakukan penguatan dengan materi agama, sebab materi agama bagi perempuan merupakan kebutuhan untuk lebih meningkatkan martabatnya sebagai manusia dan sebagai tuntunan selama hidup ke arah yang lebih mulia, sehingga perempuan benar-benar akan jadi pendidik yang berkualitas, berilmu, terampil, dan beriman, baik bagi dirinya, keluarga dan masyarakat sekitarnya.

Keempat, dimulai sejak dini, ini senada dengan sabda Nabi yang mengatakan bahwa: "Menuntut ilmu itu diwajibkan mulai dari sejak lahir sampai meninggal dunia". Bahkan akan lebih dini jika dimulai sejak dalam kandungan. Hal ini dilakukan, agar nantinya perempuan akan tumbuh pandai, terampil, kuat, dan beriman sebagaimana laki-laki. Berdasarkan urain tersebut di atas, terbukti dengan jelas bahwa M. Quraish Shihab selain terlibat aktif dalam berbagai kegiatan yang berhubungan dengan pengembangan pendidikan khususnya pendidikan perempuan, juga memiliki pemikiran yang berkaitan dengan pendidikan khususnya pendidikan permpuan. Selain berbicara tentang tujuan pendidikan dan metode pendidikan, juga berbicara tentang sifat pendidikan.

Ketiga aspek ini termasuk masalah yang paling penting dalam penyelenggaraan pendidikan khususnya pendidikan perempuan. Aspek-aspek pendidikan lainnya seperti aspek guru, sarana, materi pengajaran, lingkungan pendidikan juga tak kalah penting dalam mewujudkan pendidikan yang baik. Untuk itu, secara garis besar pendidikan perempuan menurut M. Quraish Shihab dapat disimpulkan menjadi empat bagian yaitu: 1 . kesetaraan 2. kebebasan 3. demokrasi dan 4. keadilan. 
Pemikiran M. Quraish Shihab menurut penulis dalam bidang pendidikan tersebut tampak sangat dipengaruhi oleh keahliannya dalam bidang tafsir al-Qur'an yang dipadukan dengan penguasaannya yang mendalam terhadap berbagai ilmu lainnya baik ilmu-ilmu keislaman maupun pengetahuan umum serta konteks masyarakat Indonesia. Dengan demikian, ia telah berhasil membumikan gagasan al-Qur'an tentang pendidikan khususnya pendidikan perempuan yang selama ini masih termarginalkan dalam arti yang sesungguhnya yakni sesuai dengan ajaran al-Qur'an dan al-Sunnah, juga dengan alam pemikiran masyarakat Indonesia.

Pemikiran dan gagasan M. Quraish Shihab tersebut juga menunjukkan dengan jelas bahwa di dalam al-Qur'an terdapat ayat -ayat yang memiliki implikasi terhadap munculnya konsep pendidikan menurut al-Qur'an khususnya pendidikan perempuan yang pada gilirannya dapat dijadikan sebagai salah satu bidang kajian yang perlu mendapatkan perhatian yang cukup dari para pemikir dan peneliti di bidang pendidikan Islam. Upaya ini perlu dilakukan mengingat bahwa di dalam pemikiran M. Quraish Shihab tersebut mengisyaratkan perlunya melakukan studi secara lebih mendalam tentang pendidikan perempuan dalam perspektif al-Qur'an agar al-Qur'an tidak dijadikan tameng untuk mengekang perempuan khususnya dalam bidang pendidikan.

\section{Orientasi Pendidikan Perempuan}

M. Quraish Shihab menjelaskan, bahwa manusia yang dibina melalui pendidikan adalah makhluk yang memiliki unsurunsur material (jasmani) dan imaterial (akal dan jiwa). Pembinaan akalnya akan menghasilkan ilmu pengetahuan. Pembinaan jiwanya akan menghasilkan kesucian dan etika, sedangkan pembinaan jasmaninya menghasilkan keterampilan. Dengan menggabungkan unsur-unsur tersebut, terciptalah 
manusia dwi dimensi dalam satu keseimbangan, dunia dan akhirat, ilmu dan iman. Oleh karena itulah Quraish Shihab berpendapat bahwa dalam pendidikan Islam dikenal istilah $a d a b$ al-Din dan adab al-Dunya. ${ }^{19}$ Sementara Hasan Langgulung yang juga dikutip oleh Muhaimin dalam bukunya "Paradigma Baru Pendidikan Islam" menyatakan bahwa istilah pendidikan dalam Islam meliputi; al-Tarbiyah al-diniyah (pendidikan keagamaan), al-Ta'lim al-Din (pengajaran agama) al-Ta'lim alDiny (pengajaran keagaman), al-Ta'lim al-Islami (pengajaran keislaman), Tarbiyah al-Muslimin (pendidikan orang-orang islam), al-Tarbiyah Fi al-Islam (pendidikan orang-orang Islam), al-Tarbiyah 'Inda al-Muslimin (pendidikan di kalangan orangorang Islam), dan al-Tarbiyah al-Islamiyah (pendidikan Islami). ${ }^{20}$

Kalau uraian di atas dikaitkan dengan pembangunan Nasional yang bertujuan "membangun manusia Indonesia seutuhnya" atau lebih khusus dibandingkan dengantujuan pendidikan nasional, jelas sekali relevansi dan persesuaiannya. Dalam Garis-garis Besar Haluan Negara (GBHN) 1983 misalnya dinyatakan, sistem pendidikan nasional yang berdasarkan Pancasila serta bertujuan untuk meningkatkan ketakwaan warga Indonesia terhadap Tuhan Yang Maha Esa, membangun kecerdasan, menumbuhkan keterampilan, mempertinggi budi pekerti, memperkuat kepribadian, dan mempertebal semangat kebangsaan, agar dapat menumbuhkan manusia-manusia pembangunan yang terampil dalam membangun dirinya sendiri dan bersama-sama bertanggung jawab atas pembangunan bangsa yang dilaksanakan. ${ }^{21}$

${ }^{19}$ Abuddin Nata, Tokoh-Tokoh Pembaharuan, h. 368.

${ }^{20}$ Muhaimin, Paradigma Pendidikan Islam (Bandung: Rosda Karya, 2004), h. 36.

${ }^{21}$ M. Quraish Shihab, Wawasan al-Qur'an, h. 174.

Volume 29 Nomor 2 Juli-Desember 2018 
Dalam rumusan di atas menurut penulis, jelaslah apa yang ingin dicapai oleh $\mathrm{M}$ Quraish Shihab, yakni terbentuknya manusia Indonesia yang: 1. tinggi takwanya kepada tuhan yang maha esa, 2. cerdas dan terampil, 3. berbudi pekerti luhur dan berkepribadian, 4. memiliki semangat kebangsaan. Semuanya bertujuan untuk menumbuhkan manusia-manusia pembangunan yang dapat membangun dirinya sendiri dan bersama-sama bertanggung jawab atas pembangunan bangsa. Karena itu, pendidikan merupakan suatu pembentukan karakter, kepribadian dan kemampuan anak-anak dalam menuju kedewasaan, yang di dalamnya terdapat beberapa komponen yang suatu rangkaian yang selalu berjalan beriringan, saling melengkapi satu dengan lainnya. Komponen-komponen tersebut di antaranya: pendidik (guru), anak didik (siswa), materi, lingkungan, kurikulum, tenaga kependidikan, sarana-prasarana, dana, manajemen, dan kegiatan belajar-mengajar.

Menurut penulis, kontribusi dari pemikiran M. Quraisy Shihab lebih ditekankan pada komponen pendidik, materi, dan kegiatan belajar mengajar, sebab ketiga komponen ini yang dirasa memiliki peran urgen dalam pendidikan. Pertama, peran perempuan sebagai seorang pendidik (terutama dalam rumah tangga), yang selalu bersinggungan dengan anak demi membentuk jiwa anak menjadi anak yang shalih, cerdas, berani, dan sehat. Sungguh agung tugas seorang pendidik.

Dalam pendidikan, guru memiliki posisi strategis untuk membentuk kepribadian dan mengarahkan masa depan anak didik (siswa) sehingga dibutuhkan guru yang cerdas, ulet, terampil, sabar, dan profesional, serta memiliki sensitifitas terhadap prinsi kesetaraan (equality).

Peran guru yang cukup besar dalam proses belajar mengajar terutama dalam kelas, harus mencerminkan prinsip demokrasi dengan tidak membedakan antara siswa perempuan dan laki-laki, sebab di banyak tempat masih ditemui adanya 
pembedaan tersebut, misalnya yang disuruh menghapus papan tulis lebih sering siswa laki-laki ketimbang perempuan, siswa laki-laki sering disuruh berdiri di depan kelas jika tidak bisa menjawab pertanyaan gurunya tetapi siswa perempuan tidak, dan lain-lain.

Dari beberapa pemikiran M. Quraisy Shihab di atas dapat diringkas bahwa tidak boleh ada pemetaan antara guru laki-laki dan perempuan dalam dunia pendidikan, guru (baik laki-laki dan perempuan) harus memiliki kemampuan yang cukup dalam mendidik, guru harus bisa memperlakukan siswa (perempuan dan laki-laki) sama dalam proses belajar, dan guru harus bisa menanamkan nilai-nilai luhur terhadap anak didik.

Kedua, materi atau bahan pelajaran dalam pendidikan harus bisa mencerminkan persamaan dan keadilan, yakni tidak adanya bentuk tulisan atau pemahaman yang salah dan diskriminatif terhadap salah satu dari perempuan dan laki-laki. Al-Qur'an telah dengan jelas memposisikan keduanya memiliki kedudukan sama sehingga-sangat keliru jika masih terdapat materi ajar yang membedakan keduanya.

Meski sudah sangat jalas bahwa dalam al-Qur'an dan alSunnah tidak ada perbedaan antara laki-laki dan perempuan, namun terkadang masih terjadi, penyalah tafsiran terhadap teks agama yang dipahami keliru atau dipahami setengah dan dimasukkan dalam bahan pelajaran, seperti tentang kejadian perempuan dari tulang rusuk dan kadang pula terdapat gambargambar yang mencerminkan diskriminasi, seperti gambar ibu memasak di dapur sedang ayah menyangkul.

Mengacu pada pemikiran M. Quraisy Shihab, maka segala bentuk pemahaman terhadap teks tentang perempuan harus dipahami utuh dan tidak boleh terdapat diskriminasi terhadap perempuan dan laki-laki dalam materi pelajaran.

Ketiga, Kegiatan belajar mengajar merupakan kegiatan yang selalu dan sering dilakukan yang melibatkan guru dan 
siswa serta perangkat-perangkat lainnya, seperti metode atau media dan sarana prasarana. Dalam praktek di lapangan (kelas) seringkali pemakaian metode dan sarana prasarana masih diskriminatif, misalnya masih ada yang memetakan jika siswa perempuan harus duduk di belakang dari pada siswa laki-laki dan siswa laki-laki sering dimarahi ketimbang siswa perempuan. Sehingga bentuk-bentuk semacam ini harus dihapuskan agar nilai-nilai agama tentang kesetaraan tetap terjamin. Jika memahami pemikiran M. Quraisy Shihab tentang kedudukan laki-laki dan perempuan, maka dalam kegiatan belajar mengajar tidak boleh ada bentuk-bentuk diskriminasi pada siswa, sehingga pendidikan akan memiliki masa depan yang cerah, berkualitas dan bisa diterima oleh semua kalangan.

Berdasar dari pemikiran kontruktif M. Quraisy Shihab di atas, maka harapan bagi pendidikan nasional terutama pendidikan Islam menurut penulis adalah:

a. Bahwa pendidikan masa depan harus tetap mengacu pada prinsip demokratis dengan memberlakukan beragam metode untuk dapat menggali beragam kemampuan siswa agar dapat berperan aktif dalam pengembangan dirinya dengan mengakui perbedaan kemampuan intelektual, kecepatan belajar, sifat, sikap, dan minatnya serta tidak diskriminatif.

b. Pendidikan masa depan harus lebih inklusif dengan memberikan kuota yang sama bagi perempuan dalam semua sektor pendidikan.

c. Pendidikan masa depan harus lebih mampu menanamkan nilai-nilai luhur agama, dengan memberikan pemahaman yang universal dan benar terhadap teks atau pemahaman agama, sehingga tujuan pendidikan baik tujuan duniawi maupun ukhrawi bisa tercapai.

Dengan demikian menurut penulis, tujuan pendidikan menurut M. Quraish Shihab adalah tujuan yang bersifat 
universal berlaku untuk semua bangsa dan umat di dunia, tanpa membeda-bedakan suku, ras, dan jenis kelamin. Hal ini sejalan dengan misi diturunkannya al-Qur'an yang ditujukan untuk membawa rahmat bagi seluruh alam. Melalui pendidikan, alQur'an menginginkan terwujudnya manusia yang terbina seluruh potensi darinya, fisik, jiwa, dan akalnya sehingga terbentuk manusia yang seutuhnya, yang sesuai dengan tujuan pembangunan nasional. Manusia yang demikian itulah yang dapat melaksanakan fungsinya sebagai khalifah di muka bumi dalam rangka pengabdian kepada Tuhan.

\section{Peta Paradigma dan Pemikiran M. Quraish Shihab}

Secara kasar, sesungguhnya paradigma pendidikan dibedakan dalam tiga paradigma pemikiran, meski sebenarnya ada enam paradigma pemikiran. Namun yang paling besar konstribusinya adalah tiga paradigma pemikiran yaitu, konservatif, liberal, dan radikal atau kritis. Pertama, pendidikan perempuan menurut perspektif konservatif. Para pemikir konservatif berangkat dari asumsi bahwa ketidaksederajatan antara anggota masyarakat, antara anak dan orang dewasa, antara laki-laki dan perempuan, merupakan hukum keharusan alami, suatu hal yang mustahil dihindari serta sudah merupakan takdir Tuhan. ${ }^{22}$ Jadi, perubahan relasi bagi mereka bukanlah sesuatu yang perlu diperjuangkan karena perubahan relasi sosial, termasuk relasi kelas dan relasi gender hanya membuat manusia lebih sengsara. Dalam bentuknya yang klasik paradigma konservatif dibangun berdasarkan keyakinan bahwa masyarakat pada dasarnya tidak bisa merencanakan perubahan atau mempengaruhi perubahan sosial. Tuhanlah yang merencanakan keadaan masyarakat dan hanya Dia yang tahu makna di balik itu semua. Sehingga dengan pandangan seperti ini, golongan

\footnotetext{
${ }^{22}$ Moh Roqib, Pendidikan Perempuan, h. 11.
} 
konservatif lama tidak menganggap warga masyarakat memiliki kekuatan atau kekuasaan untuk mengubah kondisi mereka.

Namun, dalam perjalanan selanjutnya, paradigma konservatif dalam melihat persoalan ketimpangan dan ketidakadilan sosial, cenderung lebih menyalahkan korbannya. ${ }^{23}$ Bagi kaum konservatif, mereka yang menderita, yakni orang miskin, buta huruf, anak-anak, kaum perempuan, ataupun kaum tertindas lainnya mengalami nasib yang demikian karena salah mereka sendiri. Karena toh banyak orang lain yang ternyata bisa bekerja keras dan berhasil meraih sesuatu. Banyak orang ke sekolah dan belajar untuk berperilaku baik sehingga tidak dipenjara. Kaum miskin haruslah bersabar dan belajar untuk menunggu sampai giliran mereka datang karena pada akhirnya kelak semua orang akan mencapai kebebasan dan kebahagiaan. Kaum konservatif sangat melihat pentingnya harmoni dalam masyarakat dan menghindarkan konflik dan kontradiksi.

Oleh karena itu menurut penulis, bagi kaum konservatif, pendidikan diselenggarakan untuk menyiapkan anggota masyarakat agar dapat menjadi warga dalam sistem dan tradisi yang ada. Tradisi, relasi sosial, ataupun sistem sosial tidak ada yang salah sehingga harus dipertahankan. Warga masyarakat, kaum perempuan dan anak-anak, harus pandai menyesuaikan diri, tidak nakal, tidak mbalelo, atau melanggar sistem sosial itu sehingga dapat mencapai kesuksesan hidup.

Kedua, pendidikan perspektif liberal. Kaum liberal berangkat dari keyakinan bahwa ada masalah di masyarakat, tetapi bagi mereka pendidikan tidak ada kaitannya dengan persoalan politik, ekonomi, dan hak-hak asasi manusia yang harus dihormati oleh masyarakat. ${ }^{24}$ Dengan keyakinan seperti

${ }^{23}$ Moh Roqib, Pendidikan Perempuan, h. 12.

24 Misiyah, Pengalaman Perempuan, Sumber Pengetahuan Yang Membebaskan.Jurnal Perempuan, edisi.48 2005., h. 43. 
itu, tugas pendidikan juga tidak ada sangkut pautnya dengan persoalan politik dan ekonomi.

Dengan demikian, kaum liberal selalu berusaha untuk menyelesaikan pendidikan dengan keadaan ekonomi dan politik di luar dunia pendidikan dengan jalan memecahkan berbagai masalah yang ada dalam pendidikan dengan usaha reformasi kosmetik. Umumnya yang dimaksud sebagai masalah anak dan child abuse misalnya, perlunya membangun fasilitas yang memadai, memodernkan peralatan perangkat keras yang lebih canggih dan laboratorim, serta berbagai usaha untuk menyehatkan rasio dokter, pasien, murid, guru, polisi, dan masyarakat. Pandangan paradigma liberal pendidikan lebih terfokus pada usaha bagaimana membantu orang per orang untuk mencapai tujuan pendidikan dengan fokus pada usaha untuk memperbarui metode pendidikan. Selain itu, pandangan liberal juga terfokus pada berbagai investasi untuk meningkatkan metodologi pengajaran yang lebih efisien dan partisipatif. Usaha peningkatan metode pengajaran tersebut terisolasi dengan sistem dan struktur ketidakadilan kelas dan gender, dominasi budaya, dan represi politik yang ada dalam masyarakat sehingga pendidikan menjadi proses yang terisolasi dari proses sosial.

Kaum liberal dan konservatif sama-sama berpendirian bahwa pendidikan adalah a-politik, dan excellence haruslah merupakan target utama pendidikan. ${ }^{25}$ Menurut penulis, kaum liberal beranggapan bahwa masalah masyarakat dan pendidikan adalah dua masalah yang berbeda. Mereka tidak melihat kaitan pendidikan dalam struktur kelas dan dominasi politik dan budaya serta diskriminasi gender di masyarakat luas. Pendidikan justru dimaksudkan sebagai media untuk mensosialisasikan dan mereproduksi nilai-nilai tata susila keyakinan dan nilai-nilai dasar agar masyarakat luas berfungsi secara baik.

${ }^{25}$ Moh Roqib, Pendidikan Perempuan, h.14.

Volume 29 Nomor 2 Juli-Desember 2018 
Pendekatan untuk Liberal inilah yang saat ini mendominasi segenap pemikiran tentang pendidikan. ${ }^{26}$ Akar dari pendidikan ini adalah bertolak dari pandangan yang menekankan pengembangan kemampuan, melindungi hak individual dan kebebasan, serta mengidentifikasi problem dalam upaya perubahan sosial secara inskrimental demi menjaga stabilitas jangka panjang. Konsep pendidikan dalam pendidikan liberal berakar pada cita-cita tentang individualisme. Sejarah ide politik liberalisme berkaitan erat dengan bangkitnya kelas menengah yang diuntungkan oleh kaum kapitalisme. Pengaruh liberalisme dalam pendidikan dapat dianalisis dengan melihat komponen-komponennya. Komponen pertama adalah komponen pengaruh filsafat model manusia universal, yakni model manusia rationalis liberal, seperti bahwa semua manusia memiliki potensi sama dalam intelektual, atau baik tatanan alam maupun norma sosial dapat ditangkap oleh akal. Mereka adalah golongan individualis yang menempatkan individu secara atomistik, membawa pada keyakinan sosial sebagai kebetulan, dan masyarakat dianggap tidak stabil.

Pengaruh liberal ini kelihatan dalam pendidikan yang mengutamakan prestasi melalui persaingan antar murid. Rangkaian untuk menentukan murid terbaik adalah implikasi dari paham pendidikan ini. ${ }^{27} \mathrm{Di}$ samping itu menurut penulis, positivisme juga berpengaruh dalam pendidikan liberal. Positivisme sebagai paradigma ilmu sosial yang dominan dewasa ini juga menjadi dasar bagi model pendidikan liberal. Positivisme pada dasarnya adalah ilmu sosial yang dipinjam dari pandangan, metode, dan teknik ilmu alam memahami realitas.

Positivisme berasumsi bahwa penjelasan tunggal dianggap appropriate untuk semua fenomena. Oleh karena itu, mereka percaya bahwa riset sosial ataupun pendidikan harus didekati

${ }^{26}$ Moh Roqib, Pendidikan Perempuan, h.16.

${ }^{27}$ Moh Roqib, Pendidikan Perempuan, h. 17. 
dengan metode ilmiah, yakni objektif dan bebas nilai. Dengan kata lain, positivisme mengisyaratkan pemisahan fakta dan nilai dalam rangka menuju pemahaman objektif atas realitas sosial. Habermas, seorang penganut teori kritik melakukan kritik terhadap positivisme dengan berbagai kategori pengetahuan sebagai berikut. ${ }^{28}$ Pertama, instrumental knowledge atau positivisme, yakni tujuan pengetahuan adalah untuk mengobrol, memprediksi, memanipulasi, dan mengeksploitasi objeknya. Kedua, hermeneutic knowledge, yakni tugas ilmu pengetahuan hanyalah untuk memahami. Ketiga, adalah critical knowledge, yakni suatu pendekatan dengan menggabungkan kedua pendekatan sebelumnya. Pendekatan ini menempatkan ilmu pengetahuan sebagai katalis untuk membebaskan potensi manusia. Paradigma pendidikan liberal pada dasarnya sangatlah positivistik.

Ketiga, pendidikan perspektif radikal atau kritis, Pendidikan bagi aliran ini merupakan suatu arena perjuangan untuk pembebasan dari segala bentuk diskriminasi dan ketidakadilan. Jika bagi kaum konservatif pendidikan bertujuan untuk menjaga status quo, bagi kaum liberal untuk perubahan moderat, maka paradigma kritis mnghendaki perubahan struktur secara fundamental dalam relasi politik sosial, ekonomi, budaya dan pendidikan dalam konteks diselenggarakan. Bagi mereka, kelas diskriminatif gender, dan rasisme yang ada dalam suatu masyarakat tercermin pula dalam dunia pendidikan. Paham ini bertentangan dengan pandangan kaum liberal yang menganggap bahwa pendidikan terlepas dari persoalan kelas dan gender yang ada dalam masyarakat. ${ }^{29}$

28 Teori kritik adalah suatu aliran yang diasosiasikan dengan kelompok filusuf jerman yang dikenal dengan mazhab Frankfurt yang mulai bekerja di jerman tahun 1923. Sebagaiman dikutip oleh Moh. Rokib, pendidikan perempuan (Yogyakarta: Gama Media, 2003), h. xvi.

${ }^{29}$ Moh Roqib, Pendidikan Perempuan, h. 17. 
Dalam perpektif radikal, urusan pendidikan adalah melakukan refleksi kritis terhadap dominan ideologi ke arah transformasi sosial. $^{30}$ Tugas utama pendidikan adalah menciptakan ruang agar tercipta wujud sikap kritis terhadap sistem dan struktur yang diskriminatif, ketidakadilan, melakukan dekonstruksi dan advokasi menuju sistem relasi sosial yang lebih adil. Pendidikan tidak mungkin bisa bersikap netral, bersikap objektif ataupu berjarak dengan jarak masyarakat seperti anjuran positivisme. Visi pendidikan adalah melakukan kritik terhadap sistem dominan sebagai pemihakan terhadap rakyat kecil, kaum perempuan, dan anak-anak, ataupun mereka yang tetindas, didiskriminasi untuk mencipta sistem relasi sosial baru dan lebih adil. Dalam perspektif radikal, pendidikan harus mampu menciptakan ruang untuk mengidentifikasi dan menganalisis secara bebas dan kritis untuk transformasi sosial. Dengan kata lain, tugas utama pendidikan adalah memanusiakan kembali manusia atau membebaskan manusia yang mengalami-dehumanisasi karena sistem dan struktur yang tidak adil.

Dengan membaca peta paradigma dan pemikiran aliranaliran tersebut, maka penulis mudah meletakkan M. Quraish Shihab sebagai pemikir pendidikan perempuan yang kritis. Melihat tema pendidikannya seperti pendidikan bagi perempuan ataupun pendidikan untuk pembebasan dan keadilan, memudahkan memposisikan paradigma dan pemikiran $\mathrm{M}$. Quraish Shihab, karena sesungguhnya ketidakadilan sosial, eksploitasi kelas, dan diskriminasi gender adalah lebih merupakan kepedulian dari kaum pendidik radikal atau kritis dibandingkan pendidikan konservatif dan liberal. Pandangannya terhadap perempuan dengan tanpa mengadili korbannya dan usulannya bagaimana pendidikan seharusnya membebaskan kaum perempuan dari subordinasi dan marginalisasi akibat

\footnotetext{
${ }^{30}$ Misiyah, Pengalaman Perempuan, Sumber, h. 44.
} 
ideologi diskrimatif yang dianut masyarakat saat ini, sebagai cerminan dari tafsiran keagamaan masyarakat tehadap ajaran agama, mengesankan kepeduliannya terhadap persoalan ketidakadilan sosial, gugatan atas diskriminasi gender, dan persoalan sosial. Menurut M. Quraish Shihab, seperti yang difirmankan oleh Allah bahwa tidak ada perbedaan antara lakilaki dan perempuan dalam hal apapun, yang membedakan hanyalah kualitas ketakwaannya terhadap Allah. Sungguhpun demikian, masih banyak yang perlu ditelusuri lebih lanjut bagaimana M. Quraish Shihab menerjemahkan pendidikan pembebasan kaum perempuan itu ke dalam metode pendidikan ataupun praktek pendidikan yang membebaskan.

Sesungguhnya menurut penulis, persoalan besar yang sering dijumpai justru adanya kesulitan banyak pemikir ataupun pengikutnya untuk membentangkan jembatan titian antara paradigma pemikiran pendidikan perempuan dengan praktek metode dan relasi guru murid yang membebaskan di sekolah. Karena antar pemikiran teoretik pendidikan pembebasan perempuan dengan metodologi pendidikan yang membebaskan erat kaitannya dalam proses transformasi sosial menuju sistem sosial yang adil dan manusiawi maka sekali lagi eksperimentasi perlu diimplementasikan dalam kehidupan sehari-hari. Agar manusia yang diciptakan oleh Allah sebagai khalifah di bumi dapat melaksanakan apa yang telah diperintahkan oleh Allah.

\section{Penutup}

Setelah melakukan studi kritis terhadap pemikiran M. Quraish Shihab yang berkaitan dengan pendidikan perempuan baik tentang tujuan, metode, materi serta aplikasinya, maka dapat diambil kesimpulan sebagai berikut,

1. Pendidikan perempuan menurut M. Quraish Shihab dapat diketahui, pertama, bahwa pendidikan perempuan harus lebih ditekankan pada prinsip saling berbagi dalam 
meningkatkan kualitas bukan kompetensi untuk menang dan kalah. Kedua, kontinu melakukan pemberdayaan, baik dilakukan secara formal maupun non formal. Ketiga, melakukan penguatan dengan materi agama. Keempat, dimulai sejak dini.

2. Orientasi pendidikan perempuan menurut M. Quraish Shihab adalah orientasi pada unsur material (jasmani) dan imaterial (akal dan jiwa). Pembinaan akalnya akan menghasilkan ilmu pengetahuan. Pembinaan jiwanya akan menghasilkan kesucian dan etika, sedangkan pembinaan jasmaninya menghasilkan keterampilan. Dengan menggabungkan unsur-unsur tersebut, terciptalah manusia dwi dimensi dalam satu keseimbangan, dunia dan akhirat, ilmu dan iman. Itu sebabnya dalam pendidikan Islam dikenal istilah adab al-Din dan adab al-Dunya.

3. Peta paradigma dan pemikiran M. Quraish Shihab merupakan kritik terhadap paradigma konservatif dan liberal. Pandangannya terhadap perempuan dengan tanpa mengadili korbannya dan usulannya bagaimana pendidikan seharusnya membebaskan kaum perempuan dari subordinasi dan marginalisasi akibat ideologi diskrimatif yang dianut masyarakat saat ini, sebagai cerminan dari tafsiran keagamaan masyarakat tehadap ajaran agama, mengesankan kepeduliannya terhadap persoalan ketidakadilan sosial, gugatan atas diskriminasi gender, dan persoalan sosial. 
Pendidikan Perempuan... Oleh: Dhomirotul F. \& Zaenal Arifin

\section{DAFTAR PUSTAKA}

Al-Qur'an dan Terjemahnya. Jakarta : CV. Samara Mandiri, 1999.

Barry, M. Dahlan Al. Kamus Ilmiah Populer. Surabaya, Arkola, 1994.

Djumransjah. Dimensi-dimensi Filsafat Pendidikan Islam. Malang: Kutub Minar, 2005.

Fadhlullah, Sayid Muhammad Husain. Dunia Wanita dalam Islam. Jakarta: Lentera, tt.

Gade, Firthiani. Ibu Sebagai Madrasah dalam Pendidikan Anak, Jurnal Ilmiah Didaktika, Vol. XIII, No. 1, Agustus 2012.

Misiyah, Pengalaman Perempuan, Sumber Pengetahuan Yang Membebaskan. Jurnal Perempuan, t.t.p: t.p., 2005.

Muhaimin. Paradigma Pendidikan Islam. Bandung: Rosda Karya, 2004.

Mukhtar, Naqiyah. M. Quraish Shihab Menggugat Bias Gender Para Ulama, Journal of Qur'an and Hadith Studies, Vol. 2, No. 2 (2013): 189-208

Muslikhati, Siti. Feminisme dan Pemberdayaan Perempuan dalam Timbangan Islam. Jakarta: Gema Insani, 2004

Nata, Abuddin. Tokoh-tokoh Pembaharuan Islam di Indonesia. Jakarta: Raja Grasindo, 2005.

Rokib, Moh. Pendidikan Perempuan. Yogyakarta: Gama Media, 2003.

R, Magdalena, "Kedudukan Perempuan dalam Perjalanan Sejarah (Studi Tentang Kedudukan Perempuan dalam Masyarakat Islam)" 2 (2013): 6.

Shihab, M. Quraish. Wawasan Al-Qur'an. Bandung; Mizan, 2004. 
Pendidikan Perempuan... Oleh: Dhomirotul F. ES Zaenal Arifin

Wartini, Atik. Tafsir Feminis M. Quraish Shihab; Telaah Ayatayat Gender dalam Tafsir al Misbah, Palastren, Vol. 6, No. 2, Desember 2013.

Wasito. Pendidikan Multikultural TRIBAKTI Jurnal Kebudayaan Dan Pemikiran Keislaman. Kediri: IAIT Kediri, 2010. 